\title{
Marketing w social media
}

Streszczenie: Precyzyjna definicja marketingu w social media jest trudna do ustalenia, jednakże można stwierdzić, że jest to metodyczne wykorzystywanie nowych technologii oraz sieci społecznych w celu realizacji określonych zadań marketingowych. Marketing w social media oznacza promocję prowadzoną za pośrednictwem różnorodnych środków przekazu, skutkującą uzyskaniem jak największej rozpoznawalności. Marketing w social media może także odnosić się do promowania określonych celów społecznych, takich jak działalność organizacji pozarządowych czy promocja działań obywatelskich.

Słowa kluczowe: marketing, media społecznościowe, promocja

\section{Cechy mediów społecznościowych}

$M_{s}^{\text {est }}$ edia społecznościowe (social media) są mediami charakteryzującymi się wysokim stopniem interaktywności, wykorzystującymi powszechnie dostępne i rozbudowane techniki komunikacji. Media społecznościowe opierają się na sieciowych, niejednokrotnie mobilnych technologiach, zmieniając wymiar komunikacji i akcentując rolę dialogu. Andreas Kaplan i Michael Haenlein [2010: 59] definiują media społecznościowe jako grupę aplikacji, opartych na technologii sieciowej, bazujących na ideologicznych i technologicznych podstawach Web 2.0, pozwalających tworzyć i wymieniać treści generowane przez użytkowników (user-generated content). W biznesie internetowe media społecznościowe niejednokrotnie są określane mianem mediów generowanych przez konsumentów (consumer-generated media). Tym, co wiąże wszelkie definicje tego zjawiska, jest połączenie technologii i interakcyjności, w wyniku którego są tworzone nowe treści. 
Media społecznościowe różnią się od tradycyjnych m.in. ceną - są raczej niedrogie, umożliwiają każdemu, niezależnie od statusu, dostęp do informacji - zarówno do jej odbioru, jak i nadawania i publikowania, w przeciwieństwie do mediów tradycyjnych, które na ogół wymagają posiadania specyficznego zaplecza od osób, chcących publikować informacje. Cechą, łączącą tradycyjne i nowe media, jest zdolność przyciągania znacznej liczby odbiorców - zarówno blog, jak i program telewizyjny mogą zainteresować kilku bądź kilka milionów odbiorców. Wśród cech, odróżniających media społecznościowe od tradycyjnych, można wymienić:

- zasięg - zarówno media tradycyjne, jak i społecznościowe mają możliwość dotarcia do licznych odbiorców. Media tradycyjne jednakże na ogół wykorzystują typowe ramy organizacyjne dla produkcji i rozprzestrzeniania informacji, podczas gdy media społecznościowe są z natury bardziej zdecentralizowane oraz mniej zhierarchizowane;

- dostęp - środki produkcji mediów tradycyjnych zazwyczaj należą do rządu lub prywatnych właścicieli; media społecznościowe są powszechnie dostępne licznym odbiorcom bezpłatnie lub za niewielką opłatą;

- użytkowanie - tworzenie treści, przekazywanych przez media tradycyjne, zazwyczaj wymaga wyspecjalizowanych umiejętności i wykształcenia. Nadawanie komunikatów za pośrednictwem mediów społecznościowych nie wymaga takich umiejętności - wystarczy tu zdolność korzystania z nowych technologii;

- natychmiastowość - czas, który upływa pomiędzy nadaniem komunikatu za pośrednictwem tradycyjnych mediów a jego odbiorem, może sięgać nawet miesięcy. Social media stanowią natomiast przestrzeń natychmiastowej reakcji, będąc wzorem dla mediów tradycyjnych, starających się sprostać wymogom, narzucanym przez użytkowników sieci;

- trwałość - przekaz w mediach tradycyjnych, raz wyemitowany, jest niemożliwy do zmiany (nie sposób wprowadzić modyfikacji w artykule, który ukazał się drukiem), podczas gdy przekazy w mediach społecznościowych mogą ulegać zmianom niemal w tym samym momencie, w którym zostały opublikowane - zarówno przez funkcję edycji, jak i dodawania komentarzy do tekstu [Gladwell, Shirky 2011]. 
Media społecznościowe stanowią interesującą hybrydę mediów tradycyjnych i cyfrowych. Przez wspólną własność dostęp do nich mają amatorzy, jak również profesjonaliści, przy wykorzystaniu zarówno infrastruktury właściwej mediom społecznym, jak i tradycyjnym, sprofesjonalizowanym. W wydanej w 2006 roku książce Bogactwo sieci: jak produkcja społeczna zmienia rynki i wolność Yochai Benkler przeanalizował wiele aspektów tejże dychotomii i ich implikacje w kontekście wolności - zarówno ekonomicznej, jak i politycznej. Benkler [2006], podobnie jak wielu innych badaczy, używa neologizmu „ekonomia sieciowa” lub „ekonomia informacji sieciowej" do opisywania ekonomicznych, społecznych i technologicznych cech tego, co określa się mianem „mediów społecznościowych".

Andrew Keen [2006: 15] krytykuje je w książce Kult amatora, pisząc, że jedynym prawem, rządzącym obecnie siecią, jest nowy cyfrowy darwinizm, pozwalający na przeżycie (czyli, w tym wypadku, na bycie usłyszanym) jedynie najgłośniejszym osobnikom, zyskującym jak najwięcej pochlebnych opinii. Jedynym sposobem na intelektualne zwycięstwo wydaje się więc permanentny bierny opór.

Tim Berners-Lee [2010] stwierdza, że niebezpieczeństwem mediów społecznościowych jest fakt, że stanowią one ogromny zbiór danych, których nie można w dogodny sposób przenosić $z$ jednej strony na inną. Ostrzega również przed serwisami społecznościowymi, które rozrastają się w niekontrolowany sposób i stają się monopolistami, ograniczającymi możliwość wprowadzania innowacji.

\section{Rola mediów społecznościowych}

Ponad połowa Polaków korzysta z Internetu. Wyniki badania Megapanel, przeprowadzonego przez PBI/Gemius, wskazują, że $12 \mathrm{mln}$ osób odwiedza portal nk.pl (dawna Nasza Klasa). 4,2 mln ma konta na Facebooku (według Social Bakers), 34\% internautów jest aktywnych na forach i grupach dyskusyjnych (według CBOS), a 16\% prowadzi blogi (według ARC Rynek i Opinia). Nie jest znana dokładna liczba użytkowników YouTube - administratorzy serwisu lakonicznie wskazują liczbę, oscylującą wokół kilku milionów. Należy do tego doliczyć tysiące forów internetowych, platformy mikroblogowe, społeczności, serwisy multimedialne, demotywatory oraz serwisy mobilne. Nie sposób nie zauważyć i nie docenić tego faktu. Nie 
sposób również nie myśleć o wyżej wskazanych użytkownikach sieci jako o kilkudziesięciu milionach potencjalnych lub aktualnych konsumentów [Krzosek, Hupa 2011: 4].

Dlaczego warto docierać do tych osób? Media społecznościowe opierają się na relacjach międzyludzkich, dzięki czemu użytkownicy Internetu samodzielnie przekazują między sobą opinie o markach i - chcąc nie chcąc - biorą na siebie rolę pracowników działów marketingu i PR. Ten efekt sieciowy wspiera wzrost świadomości marki, ponieważ zainteresowane osoby dyskutują na istotne dla nich tematy zarówno online, jak i offline. Im więcej osób będzie dyskutować o marce w społecznościach, tym więcej osób ją dostrzeże. Rozprzestrzenianie się pozytywnych opinii sprzyja rekomendowaniu marki wśród znajomych. W internetowych społecznościach podstawową stawką jest bycie dostrzeżonym przez innych. Osoby przekonane do marki będą tym chętniej się o niej wypowiadać i przekonywać swoich znajomych, zarówno w sieci, jak i poza nią. Wzrost świadomości marki i optymalne działania wspierające rekomendacje pozwalają w mediach społecznościowych na dotarcie do użytkowników i osiągnięcie ostatecznego celu biznesowego - wzrostu sprzedaży produktów i usług w Internecie oraz w "realu". W jaki sposób dotrzeć do tych osób i wykorzystać potencjał mediow społecznościowych? Jaka wiedza okazuje się przydatna [Krzosek, Hupa 2011: 4]?

Można wskazać cztery kategorie, tworzące media społecznościowe: użytkowników, kanały komunikacji, społeczności i treści. Użytkownicy mediów społecznościowych codziennie szukają w nich informacji i porad związanych z markami i produktami. Wymieniają się opiniami, dyskutują i kłócą się. Odnoszą się do wszystkich istotnych dla nich marek i oczekują, że ktoś im odpowie. Warto wiedzieć, na jakie informacje trafiają, ilu $z$ nich umieszcza w sieci swoje opinie, jak wiele tych informacji jest pozytywnych i negatywnych. Kanały komunikacji, dzięki którym tworzą się społeczności, to setki tysięcy blogów, mikroblogów, forów i portali społecznościowych - platform służących do zawierania znajomości, interakcji i zarządzania grupami ludzi (plemionami skupionymi wokół różnych tematów). To przestrzeń, w której władza jest rozproszona pomiędzy markę, agencje prowadzące działania komunikacyjne oraz - przede wszystkim konsumentów. Optymalne kanały komunikacji umożliwiają dyskusję wielu osobom, pozwalają liderom opinii na docieranie do wielu internautów i wspierają interaktywne dyskusje. Społeczności to grupy wykorzystujące różne kanały komunikacyjne do zawierania i podtrzymywania znajomo- 
ści, dyskusji i wymiany informacji. To w ich ramach najsilniej działają mechanizmy rekomendacyjne i najprościej można zwiększyć zaangażowanie. Istotne jest, aby wiedzieć, w których społecznościach najwięcej się mówi o markach i produktach. Niektóre z nich bardziej angażują uwagę konsumentów, a w innych zaangażowanie ogranicza się do kliknięcia przycisku „lubię to". Aby zrozumieć społeczności, trzeba móc odpowiedzieć na pytanie, dlaczego internauci chcą w nich uczestniczyć i w jaki sposób chcą tam zaistnieć. Treści w mediach społecznościowych są tym, na co użytkownicy trafiają i czym się wymieniają. Są tam zarówno informacje bezwartościowe, jak i opinie oraz najnowsze wiadomości, natychmiast przez wszystkich rozchwytywane. Treści mogą umieszczać wszyscy - internauci, przedstawiciele marek i komercyjni dziennikarze. Każdy, kto chce realizować w social media własne działania komunikacyjne, powinien wiedzieć, jaki efekt mogą przynieść - ile osób je zauważyło, kto i w jaki sposób na nie zareagował, czy zmienił się wizerunek marki [Krzosek, Hupa 2011: 5].

\section{Społeczności w Internecie}

Jedną z metod, stosowanych w marketingu internetowym, jest buzz marketing, po polsku nazywany marketingiem szeptanym. To działanie opierające się na wykorzystywaniu relacji społecznych, którego istotą jest przekazywanie komunikatów przez znające się osoby. W pierwszym kroku należy odnaleźć lub wykreować liderów opinii, którzy przekazują istotne dla przedstawicieli danej marki treści swoim znajomym, mając nadzieję, że ci z kolei opowiedzą o nich kolejnym osobom. W Internecie marki docierają do użytkowników - najczęściej forów lub portali społecznościowych (także blogów), którzy utrzymują znajomości z jak największą liczbą innych internautów. Relacje w społecznościach przyjmują określone właściwości, które są badane na gruncie nauk społecznych. W buzz marketingu wykorzystywany jest rozkład liczby znajomych, opracowany na gruncie analizy sieci społecznych, pokazujący, że członków społeczności można podzielić na małą grupę osób mających wielu znajomych i dużą grupę osób mających niewielką liczbę znajomych [Hupa 2011: 54].

Członków pierwszej grupy można nazwać liderami opinii (ich rolę dokładniej opisuje teoria dyfuzji innowacji). Nie zawsze jednak wskazanie dowolnego lidera opinii umożliwia dotarcie do jak największej liczby osób. Społeczności charakteryzują się również innymi właściwościami, 
które można ustalić, analizując ich makrostrukturę. Społeczności można analizować, badając sieć relacji pomiędzy ich członkami, w której węzły reprezentują osoby, a połączenia - liczbę wspólnych konwersacji lub linków internetowych. Realizacja badań tego typu wskazuje na istnienie pewnych regularności w występujących w Internecie sieciach znajomych, które można określić jako najczęściej występujące modele komunikacji. W każdym z nich działania marketingu szeptanego muszą zostać przeprowadzone w różny sposób [Hupa 2011: 55].

Jeden z modeli funkcjonowania społeczności internetowych można określić roboczo mianem „wszyscy znają wszystkich”. Przykładem tego typu społeczności jest forum wizaz.pl, na którym większość użytkowniczek wzajemnie się zna. Większość użytkowniczek wypowiada się również w ramach zróżnicowanych wątków, a każda wypowiedź jest szybko dostrzegana przez pozostałych użytkowników. Użytkowniczki oczekują wzajemnie od siebie określonej liczby wypowiedzi, a rozmowy, chociaż podzielone na kategorie, są prowadzone na każdy temat. Nie można tu wskazać wyraźnych liderów opinii jedynie na podstawie liczby wypowiedzi. Ten pozorny egalitaryzm przesłania fakt istnienia hierarchii. Użytkownicy dzielą się na grupy skupione wokół najbardziej doświadczonych i charyzmatycznych forumowiczek, a o przynależności do poszczególnych grup decyduje aktywność w relacjach $z$ administratorami oraz specjalizacja w ramach określonych tematów. W tego typu społecznościach kluczowe jest poznanie liderów w poszczególnych kategoriach tematycznych, którzy to liderzy wywierają silny wpływ na całą społeczność. Zaangażowanie ich w dyskusję o danej marce może przynieść najlepsze rezultaty [Hupa 2011: 55].

Innym modelem funkcjonowania społeczności jest model społeczności eksperckich. Niektóre społeczności skupiają się wokół określonych dziedzin życia. Wszyscy ich uczestnicy poszukują określonej wiedzy i oczekują od siebie nawzajem kompetencji w danym obszarze. Najbardziej aktywni użytkownicy walczą o prestiż wśród pozostałych. Przykładem może być społeczność majsterkowiczów na forum marketu Castorama. Tutaj dyskusja odbywa się w ramach najbardziej istotnych tematów i wątków, dotyczących remontów, budowy domów czy ogrodnictwa. Uczestników społeczności można wyraźnie podzielić na dwie grupy. Z jednej strony są stali bywalcy, którzy aktywnie komentują nowe produkty i doradzają pozostałym. Inne osoby przychodzą tutaj z określonymi problemami i pytaniami. Mogą się włączyć w istniejące dyskusje, a także samodzielnie zadawać pytania. Odpowiadają na nie eksperci lub peryferyjni członkowie społeczno- 
ści. Tego typu społeczności zakładane w celach komercyjnych są określane mianem Q/A - pytanie i odpowiedź. Jak się okazuje, specjaliści, zajmujący się public relations, odtwarzają zjawisko, które już istnieje. Jakkolwiek łatwo jest komunikować się z mniej aktywnymi członkami, o wiele trudniej jest nawiązać relacje z ekspertami. Ponieważ wzajemnie się znają i rywalizują o prestiż, można ich określić mianem zamkniętych grup. Dlatego optymalne jest zwrócenie się do nich z prośbą o opinie i poradę, która może wywołać największą reakcję i zaangażować wszystkich, których dotyczą podobne problemy. Społecznościami eksperckimi są markowe Fan Pages na Facebooku, blogosfera kulinarna czy społeczności bukmacherskie [Hupa 2011: 56].

Innym typem społeczności, który można wyróżnić, są społeczności typu „ul”. W dużych społecznościach wszyscy użytkownicy nie mogą znać siebie nawzajem. Dyskusje w takich społecznościach ogniskują się wokół doraźnych tematów - szybko się pojawiających i równie szybko znikających. To właśnie tematy - nowości, pytania i problemy angażują uwagę zainteresowanych użytkowników i inicjują dyskusję, a autorytety schodzą na dalszy plan. Wypowiedzi są krótkie, a rozmiar dyskusji zależy od stopnia zainteresowania tematem dyskusji w społeczności. Dzięki temu społeczności tego typu szybko reagują na istotne wydarzenia (co skądinąd może posłużyć do badania wagi problemu), a dyskusja jest urywana i bardzo okrojona. Liderzy opinii w tego typu społecznościach najczęściej dominują w wybranych wątkach, gdzie podtrzymują interakcję, a w pozostałych wypowiadają się rzadziej, starając się przyciągać innych użytkowników do wątków, w których są ekspertami. Prowadzenie działań komunikacyjnych w tego typu społecznościach powinno wykorzystywać metody "partyzanckie", tzn. rozpoczynanie licznych wątków w nadziei, że któryś z nich przyciągnie uwagę dużej liczby uczestników. Mogą to być konkursy, kontrowersyjne wypowiedzi czy też intrygujące pytania. Inną możliwością jest próba nawiązania kontaktu z liderami opinii, których wątki odwiedza liczne grono pozostałych osób. Przykładami tego typu społeczności jest forum gazeta.pl i dyskusje prowadzone pomiędzy użytkownikami portalu Facebook [Hupa 2011: 56-57].

Modele społeczności są oparte przede wszystkim na stopniu, w jakim społeczności są wewnętrznie podzielone. Analiza sieci społecznych umożliwia wskazanie wiązek użytkowników - osób, które komunikują się częściej wzajemnie niż z innymi internautami, i najbardziej istotnych dla nich tematów. Dzięki temu możliwe jest wskazanie nie tylko liderów opinii, ale 
i podziałów panujących w społecznościach, dzięki czemu łatwiej jest powiedzieć, co jest istotne dla internautów. Metody analizy sieci społecznych umożliwiają niemal natychmiastowy wgląd w społeczności, możliwy do odtworzenia i analizy nawet przez jedną osobę [Hupa 2011: 57].

\section{Media paid, owned, earned}

Rozwój technologii, fragmentaryzacja mediów oraz wielość punktów kontaktu z odbiorcami stawia przed specjalistami, zajmującymi się marketingiem w sieci, nowe zadania. Paradoksalnie, pomimo rozwoju technologii informacyjnych, nigdy jeszcze nie było tak trudno skutecznie skomunikować się $z$ adresatem przekazu reklamowego. Coraz trudniej jest także pozyskać jego uwagę, ,"kupując" przestrzeń reklamową, a więc wykorzystując media płatne (media paid). Ich rola w komunikacji jest oczywiście ciągle istotna, ale niewątpliwie ulega zmianie. Obecnie coraz większe znaczenie i wpływ na efekty działań marketingowych ma sfera, którą trudno zdefiniować i wycenić. Żaden budżet reklamowy nie zagwarantuje zaangażowania, zaufania, rekomendacji czy pozytywnych opinii o danej marce. Są to obszary, w przypadku których rośnie znaczenie nowych typów mediów. Coraz bardziej liczy się to, co przedstawiciele marki sami stworzą i zaproponują konsumentom, aby pozyskać ich uwagę i czas (media owned), oraz opinie o marce, jakie w wyniku działań marketingowych będą obecne w przestrzeni społecznej (media earned). Właśnie na tym polu toczy się współczesna rywalizacja o pozytywne opinie i poparcie konsumentów. Ograniczenie działań marketingowych wyłącznie do kupowania bezpośrednich przekazów reklamowych w płatnych mediach nie zbuduje obecnie przewagi konkurencyjnej. Jedynie te marki, które w pełni wykorzystają potencjał mediów owned i earned oraz umiejętnie wkomponują je w globalne strategie marketingowe, zyskają zainteresowanie odbiorców-użytkowników mediów społecznościowych [MEC 2011].

Media paid to takie, w których marketer płaci za umieszczenie przekazu reklamowego, nie mając pełnej kontroli nad formą przekazu, ale mając wpływ na treść (np. spoty reklamowe w TV, reklama w prasie, radiu, kinie, reklama typu display w Internecie czy też linki płatne w Google SEM). Zaletą tego typu mediów jest zasięg, możliwość szybkiego dotarcia z komunikatem do konsumenta. Wadą jest clutter - „szum" reklamowy, natłok obcych, konkurencyjnych informacji komercyjnych, obniżający sku- 
teczność przekazu reklamowego danej marki. Termin ten najczęściej jest używany w odniesieniu do reklam emitowanych w telewizji. Zjawisko to występuje w szczególności w najbardziej atrakcyjnych dla reklamodawców okresach (np. w grudniowym okresie przedświątecznym i świątecznym) [MEC 2011]. Clutter powoduje zmniejszający się wpływ mediów tego typu na generowanie świadomości. Jeszcze istotniejsza wydaje się malejąca efektywność mediów paid w generowaniu pożądanej reakcji konsumenta, który jest sceptycznie nastawiony do komunikatu reklamowego [MEC 2011].

Media owned emitują treści stworzone przez market era, nad którymi ma całkowitą kontrolę co do treści, jak i formy (np. strona internetowa marki, siły sprzedażowe, direct marketing, eventy, broszury itd.). Zaletą tego typu kanałów jest to, że podają one wyłącznie zamierzone, sprofilowane informacje dotyczące danej marki. Wadą jest potencjalnie mniejszy zasięg - trzeba aktywnie nakłonić konsumenta do interakcji z daną treścią (nie dostaje on jej "mimochodem” jak w mediach paid). Trudno więc skłonić dużą część grupy docelowej do kontaktu z kanałami owned [MEC 2011].

Konsumenci w dobie mediów społecznościowych coraz częściej poszukują informacji o produktach z niezależnych od reklamodawcy źródeł w mediach typu earned. Media earned to takie, w których marka musi „zasłużyć" na wzmiankę o sobie, ponieważ jej źródłem są sami konsumenci (lub np. dziennikarze w przypadku PR). Wadą mediów earned jest to, że nadawca nie ma bezpośredniego wpływu na treści na temat marek $w$ tego typu mediach (fora internetowe, blogi, media społecznościowe, user-generated content, opinie, porównywarki itd.). Zaletą tego typu mediów jest to, że mają największy bezpośredni i jednostkowy wpływ na sprzedaż. Konsumenci ufają bardziej swoim znajomym niż komunikatom reklamowym tworzonym przez marketera. Odbiorcy obecnie sami przejmują rolę aktywnego poszukiwacza komunikatów komercyjnych. Poszukują oni treści konkretnie opisujących produkt danej marki w mediach owned oraz opinii innych osób lub analizują zachowania konsumpcyjne innych osób (np. przez ich deklaracje na profilu w serwisie Facebook) i na tej podstawie podejmują decyzje zakupowe [MEC 2011].

Podział paid/owned/earned nie jest nowy. Marki zawsze tworzyły własne kanały docierania do odbiorców i zawsze istniało zjawisko polecania produktów. To, co się zmienia, to jednak znaczne wzmocnienie się roli mediów owned i earned dzięki cyfryzacji. Konsumenci zyskali istotne narzę- 
dzie w postaci możliwości dowolnego i łatwego dostępu do treści owned i earned za pomocą wyszukiwarek (głównie Google) oraz mediów społecznościowych (takich jak Facebook) [MEC 2011].

Czy zatem zmieni to sposób, w jaki media wpływają na decyzje konsumenckie? Nie można udzielić na to pytanie jednoznacznej odpowiedzi. W przypadku wielu kategorii zachodzące obecnie zmiany są gwałtowne, jednakże istnieją też takie kategorie, $w$ których rola mediów paid w procesie decyzyjnym zawsze będzie dominująca. Wyznacznikiem tego typu kategorii jest to, na ile dany zakup jest istotny dla konsumenta (wartość mierzona za pomocą oceny sum, wydawanych na dany produkt, poziomem zaangażowania w zdobycie produktu oraz oceną postrzegania marki jako składnika tożsamości konsumenta). Jeśli więc mamy do czynienia z nisko angażującym produktem (jak np. środki czyszczące), rola mediów owned i earned będzie znacznie mniejsza niż np. w przypadku kategorii samochodów czy też ubrań, finansów itd. [MEC 2011].

Taki podział mediów pozwala zredefiniować strategię komunikacyjną. W sytuacji, w której budowanie przewagi konkurencyjnej w mediach paid jest coraz trudniejsze z uwagi na clutter i sceptycyzm konsumentów, umiejętność zarządzania przestrzenią owned i earned i integrowania jej z mediami paid staje się kluczową determinantą budowania przewagi konkurencyjnej w komunikacji [MEC 2011].

\section{Budowanie „społecznego autorytetu" w mediach społecznościowych}

Jednym z kluczowych komponentów skutecznej implementacji kampanii marketingowej w mediach społecznościowych jest budowanie „społecznego autorytetu". Tworzy się on i rozwija, kiedy jednostka lub organizacja określa siebie samą jako eksperta w danej dziedzinie, a przez to staje się w niej wpływowa [Brauer, Bourhis 2006: 355].

To dzięki procesowi budowania społecznego autorytetu media społecznościowe są efektywne. Dlatego też jednym z konceptów, na których opierają się media społecznościowe, jest założenie, że nie można całkowicie kontrolować wyemitowanego za ich pośrednictwem komunikatu, można natomiast partycypować w wymianie poglądów, przyczyniając się do wzbogacenia dyskusji wprowadzanymi przez siebie wątkami 
[Rutledge 2010]. Jako że odbiorcy, a zwłaszcza użytkownicy mediów społecznościowych są szczególnie wyczuleni na działania marketingowe, należy zwrócić szczególną uwagę na sposób, w jaki przebiega owa partycypacja. Jest to kluczowe przy budowaniu autorytetu społecznego, dla którego najistotniejszą wartością jest zaufanie. Osoba, prowadząca kampanię marketingową w sieci, nie powinna oczekiwać od użytkowników, że będą podatni na przekazywane wprost treści promocyjne. Badanie „Barometr zaufania", przeprowadzone w 2008 roku, wykazało, że większość (58\%) respondentów twierdzi, że najbardziej ufa firmom i produktom poleconym przez osoby im podobne - taka informacja spotyka się z większym zaufaniem. Podobne badanie z roku 2010 wykazało jednak pewien zwrot - $64 \%$ badanych preferowało informacje, otrzymane od ekspertów i naukowców. Według ośrodka badawczego, który przeprowadził sondaż, taka utrata zaufania do innych konsumentów i zwrot w kierunku ekspertów wydaje się korelować ze wzrostem znaczenia mediów społecznościowych [Leary 2010].

Wykorzystanie mediów społecznościowych jako przestrzeni dla marketingu pociąga za sobą nowe wyzwania. Jak wskazuje badanie poziomu zaufania z 2010 roku, najlepsze wyniki w mediach społecznościowych uzyskują kampanie marketingowe, oparte na rzetelnym budowaniu zaufania i autorytetu. Należy za pomocą jasnych i czytelnych środków przekonać odbiorców o szczerości intencji, o wiedzy i specjalizacji w określonej dziedzinie przez dostarczenie wartościowej, adekwatnej informacji, nienacechowanej w wyraźny sposób założeniami komercyjnymi. Jeśli uda się tego dokonać, a odbiorcy obdarzą nadawcę komunikatu zaufaniem, komunikat zacznie w naturalny sposób się rozwijać. Nadawca - niezależnie od tego, czy jest osobą indywidualną, czy też instytucją - staje się liderem, dyktuje wartości i normy, plasując się na stanowisku zaufanego "doradcy”, nie zaś podmiotu, prowadzącego działania marketingowe. Zaczyna działać mechanizm, na mocy którego odbiorcy ufają w szczerość intencji „doradcy", oferującego im określony produkt, skąd krok do kupienia danego produktu lub poparcia promowanej postaci [Linnell 2010].

Co oczywiste, istnieje wiele sposobów kreowania społecznego autorytetu - wpływ na odbiorców można wywierać np. przez pojawienie się i aktywną działalność w Wikipedii, oferującej możliwość wolnego publikowania informacji, lecz jednocześnie stosującej mechanizmy weryfikacji treści, generowanej przez użytkowników. Mechanizmy te są silniejsze i bardziej restrykcyjne, niż mogłoby się to wydawać wielu odbiorcom, przez co ro- 
śnie prawdopodobieństwo natrafienia na treści sprawdzone i wiarygodne. Kreowanie autorytetu może również odbywać się za pomocą publikowania wiarygodnych komunikatów na takich platformach, jak Facebook czy Twitter, pisania oraz dystrybucji artykułów przez specjalnie do tego stworzone serwisy, np. Ezine Articles czy Scribd, czy też dostarczanie rzetelnych odpowiedzi na platformach społecznościowych, działających na zasadzie „pytanie-odpowiedź” (EHow, Yahoo!Answers).

Wskutek oddziaływania mediów społecznościowych, pośredniego lub bezpośredniego wpływu marketingowców, działających w obszarze tychże mediów, konsumenci są skłonni (lub też bardziej skłonni niż wcześniej) podejmować decyzje o zakupie produktów, opierając się na tym, co czytają i widzą na platformach, nazywanych społecznościowymi, jednakże tylko wtedy, kiedy owe platformy reprezentowane są przez kogoś, kogo znają i komu ufają. Ponadto, badania wskazują, że organizacje są w stanie na nowo pozyskać uprzednio niezadowolonych klientów i udziałowców przez kanał, jakim są media społecznościowe [Bryant 2011]. Dlatego też celowa i starannie zaprojektowana strategia stała się integralną częścią kompletnego i ukierunkowanego planu marketingowego. Jeśli ma ona funkcjonować w mediach społecznościowych, musi przede wszystkim wykorzystywać narzędzia budowania społecznego autorytetu [Leary 2010].

\section{Praktyka Facebook marketingu}

Jeśli autorytet społeczny, przejawiający się za pośrednictwem mediów społecznościowych, wydaje się tak istotny, w jaki sposób w praktyce skutecznie prowadzić działania marketingowe w sieci? Czy są one skuteczne i opłacalne?

Specjaliści, zajmujący się marketingiem, zarówno produktu, jak i politycznym, wydają się podzieleni: część marketingowców coraz bardziej dynamicznie - wraz z rozwojem nowych technologii informacyjnych - rozpoczęła zakładanie agencji social media, działów social media i Fan Pages w serwisie Facebook każdemu ze swoich klientów, druga połowa patrzy na to całe zamieszanie mniej przychylnym okiem. Wiele osób wspomina o nieefektywności i prowadzeniu działań marketingowych na Facebooku "W ciemno", lecz należałoby znaleźć przyczyny takiej sytuacji. Wydawałoby się, że powody są dwa: synchroniczność i natłok informacji. Przeanali- 
zujmy tę kwestię na przykładzie bodaj najpopularniejszego medium społecznościowego - serwisu Facebook.

Trudno nie docenić potencjału Facebooka: ponad 500 mln zarejestrowanych użytkowników na świecie i wcale niesłabnąca dynamika wzrostu, około 6-7 mln użytkowników w Polsce. 50\% loguje się codziennie i chętnie wchodzi w interakcje $z$ innymi użytkownikami. To na Facebooku pojawiają się największe marki, popularne, zyskujące tysiące zwolenników, aplikacje. Portal ten zapewnia ponadto nieograniczone możliwości rozprzestrzeniania się informacji wirusowych.

Na tak pojmowanej popularności najbardziej korzysta Facebook, ponieważ jest promowany przez wszystkich, którzy chcą uczestniczyć w jego marketingowym sukcesie. Wystarczy spojrzeć na prawą stronę wielu popularnych stron internetowych (jak choćby słowniki sieciowe czy bezpłatne bramki SMS), żeby zobaczyć Wtyczkę Społecznościową Facebooka. Jest to wszakże zajęta powierzchnia reklamowa i bezpłatna promocja Facebooka. Rola serwisu ograniczyła się do udostępnienia narzędzia, rola zaś poszczególnych stron internetowych - do promocji całej platformy. Facebook zadbał bardzo dobrze o wrażenie: „nie ma Cię na Facebooku - nie istniejesz" i zawtórowało mu wielu, często nieświadomych nawet swojej roli ambasadorów.

Latem 2010 roku strona internetowa Top Menedżer założyła na Facebooku Fan Page, chcąc sprawdzić skuteczność oddziaływania działań marketingowych, prowadzonych za pośrednictwem tego medium. Fan Page została wypromowana i zyskała zwolenników, co pozwoliło na przeprowadzenie testów. Testy były przeprowadzane na grupie ok. 1000 fanów i sprawdzały tylko jeden parametr: klikalność w przesłane linki - wartość łatwo mierzalną. Nie mierzono wpływu efektów wirusowych (czyli polecenia, komentowania, „lubienia” itp.); sprawdzano jedynie, jaka będzie reakcja „Facebooka” (czyli, de facto, jego użytkowników) na publikowane treści, czyli ile osób wejdzie na stronę z Facebooka, bez względu na to, skąd dokładnie i czy będą to obrane przez badaczy kanały, czy efekty wirusowe.

Jaki był rezultat? Publikując codziennie przez tydzień starannie dopracowany wpis na stronie i wspierając się kilkoma wpływowymi (odznaczającymi się uznaną pozycją, zasięgiem i zaufaniem na Facebooku) osobami, testujący odnotowali wejścia z Facebooka, wahające się między 85 a 207 dziennie. Gdyby wejścia te następowały niejako „samoistnie”, bez wzmożonego zaangażowania testujących, i rosły z czasem, można by uznać efekt 
za zadowalający. Mierzono jednak też czas, jaki osoby testujące poświęcały w tym okresie na korzystanie z serwisu Facebook. Czas ten oscylował wokół 6-8 godz./dzień, do którego to czasu należy doliczyć czas potrzebny na przygotowanie artykułów i wywiadów, co daje dodatkowe 2-4 godz./dzień. Po zsumowaniu taka forma promocji wymagałaby zatrudnienia dwóch etatowych pracowników. W porównaniu do koniecznych nakładów czasu, pracy i środków finansowych, liczba wejść, jaka była ich efektem, wydaje się niewspółmierna do inwestycji. W 2010 roku stronę odwiedziło 4424 osób, przechodząc z Facebooka. Liczba ta w niewielkim stopniu różniła się od średniej liczby wejść na stronę, osiąganej bez wykorzystania narzędzia, jakim jest Facebook. W sumie stanowiły one 1,6\% wszystkich wejść, których było 269 882. Wyciągając wnioski z testów, właściciele strony szybko zmniejszyli swoje zaangażowanie w promocję na Facebooku do kilkunastu-kilkudziesięciu minut tygodniowo, a na pewien czas nawet do zera. Facebook nie dał więc efektów adekwatnych do kosztów.

Żeby to wyjaśnić, należałoby przeanalizować przyczyny, sprawiające, że marketing jest efektywny. Prostą miarą skuteczności marketingu w kwestii docierania do konsumentów jest zasięg (ile osób ma szansę odebrać komunikat) i poziom uwagi (czyli jak długo i w jakim stopniu angażujemy odbiorcę). Prymarnym celem w tym przypadku jest jak największe zainteresowanie jak największej liczby osób. Przekucie tego na sprzedaż nie jest automatyczne, jednakże zdobycie uwagi odbiorcy przyczynia się, co oczywiste, do skutecznej promocji. Nieuzyskanie uwagi odbiorcy w prosty sposób niweczy szanse na skuteczne przekazanie komunikatu.

Co z tego wynika? Kwestia zasięgu nie wymaga rozbudowanej analizy - z zasady im większy zasięg, tym lepiej dla marketingowców; im więcej osób odbierze komunikat, tym większa szansa na wywarcie pożądanego wpływu. Kwestia poziomu uwagi wydaje się jednak bardziej złożona. Inaczej planowane są działania marketingowe w sytuacji, w której prezentacja podawanych treści może nastąpić jedynie przez krótki czas, inaczej zaś - kiedy nadawca komunikatu ma dowolną ilość czasu, który może rozdysponować zgodnie ze swoimi intencjami. W drugim przypadku poziom zaangażowania jest dużo większy, odbiorca poświęca komunikatowi dużo więcej swojej uwagi i czasu, większa jest więc szansa, że zostanie do niej przekonany. Skuteczność marketingu można roboczo zobrazować prostym wzorem i przeanalizować serwis społecznościowy właśnie pod kątem tych dwóch parametrów: [Zasięg] $\times$ [Poziom Uwagi] $=$ [Skuteczność Marketingu]. 
Jak podaje serwis Facebook, jego statystyczny użytkownik ma w kontaktach 130 osób i 80 stron fanów, eventów lub/i grup. Do tego sam średnio publikuje 3 wiadomości dziennie. Podczas testów założono, że strony fanów, eventów i grup publikują podobną liczbę wiadomości, ale nawet jeśli są to wartości mniejsze, to lukę tę uzupełniają komunikaty o komentarzach wygenerowanych przez znajomych. Można więc dla uproszczenia przyjąć, że są to też 3 wiadomości dziennie. Wzmożona aktywność użytkowników serwisu przypada na godziny 8.00-24.00, zatem w sumie 16 godz./dzień, przy czym średnia liczba „znajomych” jednego użytkownika, jednocześnie aktywnych na Facebooku, wynosi około 17\%.

Proste obliczenia prowadzą do wniosku, że statystyczny użytkownik dziennie otrzymuje 630 komunikatów. Daje to średnio jeden komunikat co 1,5 minuty przez 16 godzin. Twórcy Facebooka przewidzieli taką sytuację, tworząc narzędzie, które nie wyświetla użytkownikom wszystkich komunikatów - jednocześnie otrzymują ich kilka i aby otrzymać inny zestaw, należy odświeżyć stronę. W efekcie zdecydowanie nie wszystkie komunikaty pochodzące od znajomych i subskrybowanych Fan Pages zostają wyświetlone na "ścianie” (ang. wall - nazwa, jaką twórcy Facebooka nadali profilowej stronie użytkownika serwisu). Gdyby tak było, użytkownik byłby mocno przeciążony liczbą informacji. Trudno ocenić, ile komunikatów realnie dociera do znajomych/fanów, jednak bez wątpienia nie wszystkie, które zostały wyemitowane - im więcej użytkownik ma aktywnych znajomych i Fan Pages, tym trudniej dotrzeć do niego z komunikatem.

Ponadto, ekspozycja komunikatu na Facebooku jest także krótkotrwała. Średnio 1,5 minuty od pojawienia się komunikatu zostaje on zastąpiony przez inny, nowszy. Po godzinie komunikat osiąga już 40. pozycję w kolejności informacji, a zatem niezwykle szybko się dezaktualizuje (szanse na odbiór komunikatów sprzed dnia czy tygodnia są znikome). Czas życia informacji na Facebooku nie ułatwia zadania marketingowcom, gdyż komunikat może zyskać uwagę odbiorców tylko przez krótką chwilę, po czym znika w archiwum, którego nikt już nie przegląda. Można więc obrać strategię publikowania informacji wtedy, kiedy więcej osób jest aktywnych na Facebooku, aby pozyskać potencjalnie więcej wyświetleń komunikatu, ale efekt jest słabszy niż oczekiwany: $w$ tym czasie jest też produkowanych więcej niż średnio komunikatów, więc konkurencja o uwagę także jest większa. Metody synchroniczne praktycznie zawsze są mniej skuteczne niż asynchroniczne (np. mailing). Testem takiego stwierdzenia może być zrobienie webinarium o określonej porze i sprawdzenie frekwencji. 
Kolejnym problemem, związanym z promocją na Facebooku, są opcje ukrywania komunikatów, jakie zapewnia serwis. Niezależnie od przyczyny, dla której użytkownik nie chce otrzymywać informacji, związanych z daną marką, może wybrać opcję „Ukryj wszystkie posty Użytkownika" i nigdy więcej nie otrzymać komunikatu od danego nadawcy, mimo formalnego bycia jego „fanem”. 1000 fanów nie oznacza zatem 1000 odbiorców komunikatu - ta liczba jest znacznie mniejsza. Nawet jeśli uda się skutecznie wyemitować komunikat, nie ma gwarancji, że użytkownik go przyswoi.

Mimo że jednocześnie na „ścianie” wyświetla się nawet kilkanaście komunikatów, to aby je wszystkie zobaczyć, trzeba przewijać zawartość ekranu. Nie jest to ulubione zajęcie użytkowników, więc naturalnie uwaga kierowana jest na to, co widać bez wysiłku, czyli - zależnie od rozdzielczości monitora i objętości informacji - 3-5 znajdujących się najwyżej komunikatów. Do tego należy dodać informacje o znajomych, o tym, kto jest online, wiadomości, powiadomienia, zaproszenia, wydarzenia, reklamy, chat itp. Wśród tylu komunikatów należy znaleźć sposób na wyróżnienie własnego, aby został zauważony, kiedy pojawi się na „ścianie”.

Styl konsumpcji informacji na Facebooku przypomina korporacyjny, sieciowy styl konsumpcji innych produktów - dynamiczny, lecz jednocześnie standardowy i przewidywalny. Użytkownicy odwiedzają strony, do których odnośniki zamieszczają ich znajomi, przeglądają sugerowane artykuły, jednakże następnie wracają do serwisu.

Nadawca komunikatu o charakterze marketingowym konkuruje o uwagę z wieloma innymi informacjami - opiniami o innych użytkownikach, wyrażanymi publicznie poglądami, odnośnikami do utworów muzycznych, humorystycznymi plikami wideo, fotografiami, quizami, ankietami itp. Komunikaty o charakterze ściśle marketingowym niejednokrotnie nie są wystarczająco atrakcyjne, by zyskać uwagę odbiorców. Życie społeczne interesuje ich dużo bardziej niż marki i produkty, a sprzedaż lub bezpośrednia promocja na Facebooku mogą zostać uznane za naruszenie prywatności. Osiąganie wymiernych efektów w takich warunkach wydaje się więc poddawać w wątpliwość opinię o wyłącznych zaletach marketingu w mediach społecznościowych [Ksiądzyna 2011]. 


\section{Czego robić nie należy - błędy marek w mediach społecznościowych}

Analizując rolę marki w mediach społecznościowych, należy zwrócić uwagę na katalog błędów, najczęściej popełnianych przez osoby lub zespoły, odpowiedzialne za prowadzenie działań marketingowych w sieci, a szczególnie w mediach społecznościowych.

Prowadząc dialog z użytkownikami, którzy dołączyli do profilu danej marki w jakimkolwiek serwisie społecznościowym, należy pamiętać o zapewnieniu użytkownikowi możliwości odpowiedzi na emitowany komunikat; co więcej - należy być na tę odpowiedź przygotowanym, niezależnie od jej treści. Firma HTC, chcąc nawiązać kontakt $z$ aktualnymi oraz potencjalnymi użytkownikami na Facebooku, pytała fanów, jak powinien nazywać się nowy telefon. Seria odpowiedzi, jakie zaczęły pojawiać się na profilu, z całą pewnością była zaskoczeniem. Trzeba jednak brać pod uwagę to, że w mediach społecznościowych komunikacja nie jest jednostronna. To zmiana paradygmatu z samego przekazywania treści na relację nadawca-odbiorca. Błędem jest nieuwzględnienie w planach pojawienia się sytuacji kryzysowej i działanie spontaniczne [Sosnowska 2010a].

Kolejnym błędem jest usuwanie niepochlebnych, niewygodnych komentarzy na temat danej marki z profili, zakładanych do celów marketingowych w mediach społecznościowych. Jedną z konsekwencji takiego posunięcia może być bowiem „efekt Streisand". Zjawisko nazwę swą zyskało za sprawą Barbry Streisand, która pozwała fotografa Kennetha Adelmana za opublikowanie w sieci lotniczego zdjęcia jej domu. Streisand żądała 50 milionów dolarów za naruszenie prywatności; problem w tym, że Adelman nie był paparazzim - zdjęcie domu aktorki znalazło się wśród kilkunastu tysięcy innych, dokumentujących wybrzeże Kalifornii. W wyniku nagłośnienia sprawy przez samą Streisand zdjęcie jej domu nie tylko nie zniknęło z Internetu, lecz było masowo wyszukiwane i publikowane na prywatnych stronach internautów [Sosnowska 2010b]. Skutkiem usuwania komentarzy jest naruszenie zasad komunikacji z użytkownikami. Natomiast usiłowanie ukrycia czy skasowania treści (zdjęć, filmów) prowadzi do tym większego ich spopularyzowania w miejscach, na które marki nie mają wpływu. Błędem jest ponadto ignorowanie doniesień użytkowników o niedociągnięciach produktów, narzekań na opóźnienia i wytykanie niekompetencji. Jeśli użytkownik nie jest zadowolony, to zapewne ma 
po temu ważny powód. Social media to przestrzeń, w której można rozwiązać problem, zanim użytkownicy rozpowszechnią wiadomość, że dana marka lekceważy swoich konsumentów [Sosnowska 2010a].

Osoba prowadząca publiczny profil marki musi być w stanie reagować w sytuacjach kryzysowych. Stoi bowiem w obliczu licznej grupy osób, których reakcje są nieprzewidywalne. Dlatego prowadzenie dialogu musi uwzględniać kilka czynników - kulturę wypowiedzi, strategię marketingową oraz głęboką znajomość psychologii tłumu. Kolejnym z często popełnianych błędów jest bowiem nieuwzględnienie naturalnych reakcji lawinowych. Jeśli marka popełnia niezręczność, gafę, ktoś ją z pewnością zauważy, a jeśli sam dysponuje charyzmą, pociągnie za sobą innych. Tak było w przypadku koncernu Nestlé - organizacja Greenpeace ogłosiła, że „Nestlé przyczynia się do zagłady orangutanów". Na YouTube umieszczono także dość drastyczny w wymowie film. W efekcie użytkownicy zaczęli masowo przerabiać logo szwajcarskiej firmy, co z kolei wywołało u administratora strony na Facebooku agresję, co przyczyniło się do eskalacji konfliktu w sytuacji, w której najskuteczniejsze dla koncernu byłoby jego załagodzenie [Sosnowska 2010a].

Nietrudno wpłynąć na zmianę postawy internautów w wyżej wzmiankowanej sytuacji kryzysowej. Jeśli marka popełnia błąd, może obrać strategię wypierania, lecz ta wydaje się niezbyt skuteczna, w przeciwieństwie do uznania błędu. Co ciekawe - tego rozwiązania marki raczej unikają, a to prowadzi do eskalacji wrogości. Takie podejście spowodowało rozwój „sprawy Nestlé". Administrator nie zapanował nad emocjami, zagrożono usuwaniem komentarzy. Komunikacja na portalach społecznościowych bez wątpienia jest istotna, jednakże jej pochodną musi być budowanie lojalności wśród odbiorców, a tę najlepiej zyskać, proponując promocje, produkty lub innego rodzaju bonusy, nieosiągalne w inny sposób. To sprawia, że warto wracać na profil danej marki i być jej oddanym. Jeśli nie zostaną zapewnione wyjątkowe prezenty w postaci zniżek, kuponów, drobnych upominków, marka nie będzie wyróżniać się wśród innych [Sosnowska 2010a].

Traktowanie profilu w serwisie społecznościowym jako powierzchni reklamowej to kolejny błąd, jaki może popełnić marka. Przekaz promocyjny dociera do użytkowników za pomocą wielu innych kanałów, dlatego też media społecznościowe powinny być przestrzenią, w której między marką a konsumentami dochodzi do dialogu. Media społecznościowe nie służą zapoznaniu się z ofertą handlową - do tego celu użytkownicy wykorzystują wyszukiwarki internetowe [Sosnowska 2010a]. 


\section{Jaka przyszłość social media?}

Trudno jest przewidywać trendy w mediach społecznościowych w perspektywie dalszej niż kilka miesięcy. To, czego można oczekiwać, to dalszy, intensywny rozwój serwisu Facebook w Polsce. Pomimo spodziewanego przyrostu liczby użytkowników, markom będzie coraz trudniej przyciągnąć ich uwagę. Wzrastająca rywalizacja o zainteresowanie użytkownika będzie powodowała, że coraz ciężej będzie wyemitować skuteczny komunikat. Kluczowe znaczenie ma pomysł - prosty i spektakularny. Wzorując się na przykładach marek, które dzięki takim pomysłom osiągnęły sukces, należy długofalowo budować strategię komunikacji w mediach społecznościowych, jeśli celem jest utrzymanie pozyskanych fanów przy marce. Coraz mniejszą rolę będą odgrywać przypadkowi fani, a coraz większą - osoby, które rzeczywiście będą utożsamiać się i komunikować z daną marką. Dla takich użytkowników trzeba będzie budować inne modele komunikacji - w mniejszym stopniu oparte na zabawie i interakcji, a w większym na działaniach PR i dedykowanych aplikacjach. Będą to aplikacje pozwalające z poziomu Facebooka np. na zarządzanie swoim kontem, rozmowę z konsultantem danej firmy, zakupy internetowe bez opuszczania serwisu itd. Firmy będą również zmuszone podejść do social media od strony prawnej - stworzyć politykę social media dla swoich pracowników oraz dokumenty, regulujące zasady prywatności i warunków korzystania z profili firmowych w serwisach społecznościowych [Dzieduszycka-Jędrach 2011: 66].

\section{Bibliografia}

Benkler Yochai. 2006. The wealth of networks. How social production transforms markets and freedom. New Haven: Yale University Press.

Brauer Markus, Bourhis Richard Y. 2006. Social power. „European Journal of Social Psychology" vol. 36, s. 355.

Kaplan Andreas M., Haenlein Michael. 2010. Users of the world, unite! The challenges and opportunities of Social Media. „Business Horizons” vol. 53, s. 59.

Keen Andrew. 2006. The Cult of the Amateur: How Today's Internet Is Killing Our Culture. New York: Currency.

Rutledge Patrice-Anne. 2010. The Truth About Profiting from Social Networking. New Jersey: Pearson Education. 


\section{Źródła internetowe}

Berners-Lee Tim. 2010. Long Live the Web: A Call for Continued Open Standards and Neutrality. http://www.scientificamerican.com/article.cfm?id=long-live-theweb, 1.04.2011.

Bryant Shannon. 2011. Retailers Can Win Back Unhappy Customers Through Social Media. http://www.marketingforecast.com/archives/10548, 1.04.2011.

Dzieduszycka-Jędrach Justyna. 2011. Przyszłość social media. [W:] M. Krzosek, A. Hupa (red.). Social Media Manual 2010. http://www.marketing-news.pl/ message.php?art=28775, 1.04.2011.

Gladwell Malcolm, Shirky Clay. 2011. From Innovation to Revolution. Do Social Media Make Protests Possible? „Foreign Affairs” March/April 2011. http://www. foreignaffairs.com/articles/67325/malcolm-gladwell-and-clay-shirky/frominnovation-to-revolution, 1.04.2011.

Hupa Albert. 2011. Marki w social media - 2010 rok. [W:] M. Krzosek, A. Hupa (red.). Social Media Manual 2010. http://www.marketing-news.pl/message. php?art=28775, 1.04.2011.

Krzosek Marcin, Hupa Albert. 2011. Social Media Manual 2010. http://www.marketing-news.pl/message.php?art=28775, 1.04.2011.

Ksiądzyna Michał. 2011. Cała prawda o Facebook marketingu. http://www.topmenedzer.pl/2011/01/cala-prawda-o-facebook-marketingu/, 1.04.2011.

Leary Brent. 2010. Overemphasis on Brand Building Leads to Mistrust. http://technology.inc.com/2010/03/22/overemphasis-on-brand-building-leads-to-mistrust/, 1.04.2011.

Linnell Nathan. 2010. Social Media Influence on Consumer Behavior. http://searchenginewatch.com/3640221, 1.04.2011.

MEC. 2011. III Forum MEC Interaction. http://www.mecglobal.pl/iii-forum-mec-interaction, 1.04.2011.

Sosnowska Joanna. 2010a. 10 grzechów głównych marki w social media. http:// technologie.gazeta.pl/internet/1,104663,7834241,10_grzechow_glownych_marki_w_social_media.html, 1.04.2011.

Sosnowska Joanna. 2010b. Auchan ofiara klasycznego „efektu Streisand". http:// technologie.gazeta.pl/technologie/1,81010,7538486,Auchan_ofiara_klasycznego_efektu_Streisand_.html, 1.04.2011. 


\section{Social media marketing}

Summary: The precise definition of social media marketing is hard to establish, but it can be said that it is the methodical use of new technologies and social networks to achieve specific goals for a company. In simple terms social marketing means advertising a company through many different media, like viral videos and blogs, to achieve its maximum exposure. Nevertheless, social media marketing may also refer to advertising certain social issues, such as NG0s' or civic actions' promotion.

Keywords: marketing, social media, promotion 